\title{
THE CLINICAL AND ECONOMIC ANALYSIS OF PHARMACEUTICAL PROVISION OF PATIENTS WITH DEPRESSIVE DISORDERS IN HOSPITAL ENVIRONMENT
}

\section{O.S.Yakovleva}

\author{
Zaporizhzhia State Medical University
}

\author{
Key words: depression; clinical and economic analysis; pharmaceutical provision of patients with \\ depressive disorders
}

\begin{abstract}
The results of the clinical and economic analysis of pharmaceutical provision of patients with depressive disorders in the departments of the specialized healthcare institution in 2015 are presented. It has been found that drugs for the pathogenetic treatment of depression account for the greatest number of medical prescriptions in the structure of drug consumption. Thus, according to the results of studies the greatest number of prescriptions and the highest amount of drug consumption are per three antidepressants. More than half of the resource has been spent on consumption of drugs that are essential by the requirements of the regulatory framework regulating the issues of medical care to patients with depressive disorders. Taking into account the fact that a significant number of the patients who underwent inpatient treatment had a recurrent nature of the disease further pharmacoepidemiological studies of the drug consumption should be expedient, namely determination of the rationality of prescribing drugs with the antidepressant action using the ATC-DDD methodology.
\end{abstract}

$\mathrm{T}$ he urgency of the problem of depressions is caused by their prevalence, significant influence on the quality of life, social functioning of a person in almost all areas of life: employment, family, social contacts. Depression refers to diseases that are accompanied by severe medical and social consequences, including disability, suicide, and economic losses. Indicators of disability in depressive disorders exceed similar indicators in cerebrovascular and cardiovascular diseases. According to the WHO protocol by 2020 depression will occupy the second place after ischemic heart disease among the causes of disability. In accordance with the existing standards of medical care of patients with depression the main method of treatment is pharmacotherapy with antidepressants of the latest generation [6]. The current standards of medical care of patients with depression include prescriptions of antidepressants of the last generation. Modern medicines have a sufficient level of evidence of efficacy and safety, but they are preferably expensive. The last fact should be considered for the patients who require treatment for a long time. Development of activities to provide availability of the treatment of patients based on the results of the clinical and economic analysis (CEA) is of particular relevance in this case.

Therefore, the aim of this work was to carry out the comprehensive clinical and economic analysis of the state of pharmaceutical provision for patients with depressive disorders who underwent inpatient treatment in a specialized healthcare institution.

\section{Materials and Methods}

The object of the research was the data of 196 medication administration records of the patients with depressive disorders treated in the departments of the healthcare institution in 2015.

CEA of pharmaceutical provision of patients with depressive disorder ABC-, VEN- and frequency analysis were carried out according to the methods developed and tested by domestic scientists of the Department of Organization and Economics of Pharmacy of the NUPh under the supervi- sion of professor A.S.Nemchenko. First of all, frequency analysis involves determining the frequency of prescriptions of different types of drugs according to the data of medication administration records. According to the ABC analysis all drugs were divided by the level of their investment into three groups: A - the most expensive drugs (80.0\% of the total drug consumption for a certain period of time); $\mathrm{B}$ - average-cost drugs (15.0\%); C - low-cost drugs (5.0\%) [7]. The formal approach to determine the possibility of including drugs in groups (VEN-analysis) was used. Thus, group V included drugs that were the part of the National List of essential medicines and medical devices (decree of CMU from 25.03.2009 No. 333, Budget list of drugs (decree of CMU from 05.09.1996 No. 1071 "On the procedure of drug purchase by healthcare institutions financed from the budget" amended in accordance with the Orders of MPH of Ukraine dated from 27.08.2010 No. 631, 26.04.2011, No. 170, 5.03.2012, No. 79, 7.03.2013 No. 105, the State Formulary of drugs of the VII ${ }^{\text {th }}$ edition and unified clinical protocol of the primary, secondary (specialized) and tertiary (highly specialized) medical care "Depression 
(mild, moderate, severe depressive episodes without the somatic symptom or with the somatic syndrome, recurrent depressive disorder, dysthymia" (Order of MPH of Ukraine dated from December 25, 2014 No. 1003). Group E included the names of drugs, which were absent in the National List of essential drugs and medical devices and present in all other documents, and group $\mathrm{N}$ included all the other names of drugs $[4,5]$. To calculate the amount of expenditure the data from the accounting documentation of the healthcare institution were used.

Processing of statistical data was carried out using the Microsoft Office Excel 2010 tabular processor and standard programs of applied statistical analysis Statistica 6.0.

\section{Results and Discussion}

At the first stage of our studies the analysis of the socio-demographic structure of patients according to various parameters (age, gender, social status, place of residence, the presence of comorbidities) was conducted. The age of the patients hospitalized was from 28 to 60 years. It was found that, in general, the patients were mostly women (62.2\%), and it was consistent with the literature data. A significant number of patients $(81.3 \%)$ had the recurrent nature of the disease; only 7 (3.57\%) patients underwent in-patient treatment for the first time. At the place of permanent residence urban residents $(73.98 \%$ of the total number of patients) comprised the vast majority. Among the patients, the proportion of employees was $41.67 \%$; the percentage of the most socially vulnerable people (pensioners, temporarily unemployed, I-II group disabled) was $53.1 \%$. The state almost of all patients was accompanied with concomitant comorbidity diseases.

According to the data from medication administration records the analysis of the frequency of drug prescriptions was carried out.
It was found that doctors made 1078 prescriptions of 60 names of drugs according to INN ("International Nonproprietary Name"), and there were 89 drugs by trade names.

The results of frequency analysis of prescriptions obtained allow to assert that patients with depressive disorders were primarily prescribed drugs with the pathogenetic action. Antidepressant drugs have the largest number of medicinal prescriptions. Moreover, according to INN three drugs, namely sertraline (69 prescriptions or $35.2 \%$ of all patients), fluoxetine (59 prescriptions $-30.1 \%$ ), fluvoxamine (41 prescriptions $20.92 \%$ ) had the highest rates of prescriptions. Taking into account the clinical condition of the patient such drugs as diazepam (39 prescriptions $-18.84 \%$ ), galoperidol (33 prescriptions - 16.84\%), clozapine (31 prescriptions - 15.82\%), oxazepam (29 prescriptions $14.8 \%$ ) were prescribed according to INN. In general, the group of drugs "Drugs that affect the nervous system" included 537 prescriptions or $49.81 \%$ of their total number. According to INN the number of drugs of the pharmacotherapeutic group specified was 25 or $41.7 \%$ of the range. Correction of somatic autonomic disorders also required prescription of various drugs ( 35 or $58.3 \%$ of the total range).

The next stage of the research was to rank drugs by actual drug prescription and their distribution by the $\mathrm{ABC}$ groups. Group A contained drugs, which consumption was $102912.38 \mathrm{UAH}$, or $79.55 \%$ of the total consumption, group B 20039.13 UAH $(15.49 \%)$, and group C - 6416.67 UAH (4.96\%), respectively.

Group A included 10 drugs according to INN $(16.7 \%$ of the range studied), its bulk were drugs affecting the nervous system. According to INN group B was formed of 26 drugs (43.3\%), belonging to different pharmacological groups, and group C consisted of 24 drugs (40.0\%). It should be noted that group $\mathrm{C}$ included drugs intended for the treatment of comorbidity in patients with depressive disorders.

An important characteristic of the pharmaceutical provision state of patients is that in the structure of drug consumption the names used in pathogenetic treatment of depressive disorders dominate. The consumption indicator calculated according to this group is $90208.42 \mathrm{UAH}(69.73 \%$ of the total consumption indicator).

According to the results of VENanalysis it was found that most drugs ( $43.3 \%$ of the range) were important. The proportion of drugs with the status $\mathrm{N}$ is $33.33 \%$, for them $4.96 \%$ of the costs associated with the pharmaceutical provision of patients was spent. Thus, there is a need to find the ways for further optimization of the costs for non-essential drugs.

The results of the complex CEA have proven that the largest share of expenditure $(51.89 \%)$ is related to the pharmaceutical provision of patients with depressive disorders. According to INN it comprises 5 drugs, which are the most expensive and essential; the total number of prescriptions is 247 , or $22.91 \%$ of all prescriptions.

The cost parameters of the annual drug consumption calculated per a patient were from 237,15 UAH to $1398,47 \mathrm{UAH}$. Moreover, medical prescriptions had an individual character and were in agreement with clinical guidelines. These significant variations in cost parameters of drug consumption per a patient determines the feasibility of further pharmacoeconomic studies aimed at selecting optimal treatment regimens for patients with depressive disorders.

\section{CONCLUSIONS}

1. It has been found that while patients underwent the treatment in the departments of a specialized healthcare institution 60 drugs were used according to 
INN, and 1078 drug prescriptions were made by doctors.

2. Frequency analysis of medical prescriptions has showed that the greatest number of prescriptions (537 prescriptions or $49.81 \%$ of the total prescriptions) is of the group "Drugs that affect the nervous system", the number of drugs according to INN is 25 or $41.7 \%$ of the range.
3. The total rate of consumption for patients with depressive disorders was 129368.17 UAH. According to the $\mathrm{ABC}$ analysis group A (the most expensive) includes 10 drugs that affect the nervous system according to INN.

4. VEN-analysis has showed that among the range of the drugs prescribed to the patients with depressive disorders the share of the vital drugs is $13.3 \%$, essential drugs $-53.3 \%$ and non-essential drugs $-33.3 \%$.

5. An important direction for future research is to conduct pharmacoepidemiological studies of drug consumption, namely determination of the rationality of prescribing drugs with the antidepressant action using the ATCDDD methodology.

\section{REFERENCES}

1. Авксентьева М.В., Воробьев П.А., Герасимов В.Б. и др. Экономическая оценка эффективности лекарственной терапии (фармакоэкономический анализ) / Под ред. проф. П.А.Воробьева. - М.: Ньюдиамед, 2000. - 80 c.

2. Бездітко Н.В. // Укр. вісник психоневрол. - 2013. - Т. 21, №4 (77). - С. 123-129.

3. Мищенко О.Я., Адонкина В.Ю., Чинуш И.В. // Фармац. журн. (Узбекистан). - 2013. - №1. - С. 4-9.

4. Немченко А.С., Яковлева О.С. // Управління, економіка та забезпечення якості в фармації. 2011. - №5 (19). - C. 52-57.

5. Панфілова Г.Л., Цурікова О.В. // Запорізький мед. журн. - 2014. - №1. - С. 35-39.

6. Скрипніков А.М., Гринь К.В. // Вісник ВДНЗУ «Українська медична стоматологічна академія». 2013. - №2 (42). - C. 156-158.

7. Яковлєва Л.В., Бездітко Н.В., Герасимова О.О. та ін. Фармакоекономіка. - Вінниця: Нова книга, 2009. $-208 \mathrm{c}$.

8. Drummond M.F., Schwartz J.S., Jönsson B. et al. // Int. J. Technol. Assess. Health Care. - 2008. - Vol. 24 (3). - P. 244-258.

9. Rascati K.L. Essentials of Pharmacoeconomics - Lippincott Williams \& Wilkins, 2013. - 310 p.

\section{КЛІНІКО-ЕКОНОМІЧНИЙ АНАЛІЗ ФАРМАЦЕВТИЧНОГО ЗАБЕЗПЕЧЕННЯ ХВОРИХ НА ДЕПРЕСИВНІ РОЗЛАДИ В УМОВАХ СТАЦІОНАРУ}

\section{о.С.Яковлєва}

Запорізький державний медичний університет

Ключові слова: депресія; клініко-економічний аналіз; фармацевтичне забезпечення хворих на депресивні розлади

Представлені результати клініко-економічного аналізу фармацевтичного забезпечення хворих на депресивні розлади у відділеннях спеціалізованого закладу охорони здоров'я у 2015 році. Встановлено, що у структурі споживання препаратів найбільша кількість лікарських призначень припадає на лікарські засоби для патогенетичного лікування депресії. Так, за результатами досліджень на три лікарських засоби антидепресивної дії припадає найбільша кількість призначень та найбільші витрати. Більше половини ресурсів було витрачено на споживання препаратів, необхідних за вимогами нормативно-правової бази, яка регулює питання надання медичної допомоги хворим на депресивні розлади. Враховуючи той факт, що значна кількість хворих, які перебували на стаціонарному лікуванні, має рецидивуючий характер перебігу захворювання, у подальшому необхідні фармакоепідеміологічні дослідження споживання лікарських засобів, а саме визначення раціональності призначень лікарських засобів антидепресивної дії за допомогою АTC-DDD методології.

\section{КЛИНИКО-ЭКОНОМИЧЕСКИЙ АНАЛИЗ ФАРМАЦЕВТИЧЕСКОГО ОБЕСПЕЧЕНИЯ БОЛЬНЫХ С ДЕПРЕССИВНЫМИ РАССТРОЙСТВАМИ В УСЛОВИЯХ СТАЦИОНАРА}

\section{о.С.Яковлева}

\section{Запорожский государственный медицинский университет}

Ключевые слова: депрессия; клинико-экономический анализ; фармацевтическое обеспечение больных с депрессивными расстройствами

Представлены результаты клинико-экономического анализа фармацевтического обеспечения больных с депрессивными расстройствами в отделениях спещиализированных учреждений здравоохранения в 2015 году. 
Установлено, что в структуре потребления препаратов наибольшее количество врачебных назначений приходится на лекарственные средства для патогенетического лечения депрессии. Так, по результатам исследований на три лекарственных средства антидепрессивного действия приходится наибольшее количество назначений и наибольшие затраты. Более половины ресурсов было потрачено на потребление препаратов, которые являются необходимыми по требованиям нормативно-правовой базы, регулирующей вопросы оказания медицинской помощи больным с депрессивными расстройствами. Учитывая тот факт, что значительное количество больных, которые находились на стационарном лечении, имеет рецидивирующий характер течения заболевания, в дальнейшем необходимы фармакоэпидемиологические исследования потребления лекарственных средств, а именно определение рациональности назначений лекарственных средств антидепрессивного действия с помощью АTC-DDD методологии.

Address for correspondence:

Received in 18.04.2016

26, Mayakovsky avenue, Zaporizhzhia, 69035, Ukraine.

Tel. (96) 551-91-11. E-mail: olgayakovleva.zp@gmail.com.

Zaporizhzhia State Medical University 